\title{
STUDI TIMBULAN, KOMPOSISI, KARAKTERISTIK, DAN POTENSI DAUR ULANG SAMPAH NON DOMESTIK KABUPATEN TANAH DATAR
}

\author{
Slamet Raharjo, Rima Geovani \\ Jurusan Teknik Lingkungan, Fakultas Teknik, Universitas Andalas \\ Kampus Limau Manis, Unand Padang 25163, Indonesia \\ Email: sraharjo@ft.unand.ac.id
}

\begin{abstract}
ABSTRAK
Kabupaten Tanah Datar belum memiliki data dasar persampahan, maka dilakukan penelitian untuk menentukan besaran timbulan, komposisi, karakteristik fisika (berat jenis), karakteristik kimia (kadar air, volatile, fixed carbon, abu, rasio $C / N)$, dan potensi daur ulang sampah non domestik yang dihasilkan dari kawasan komersil, institusi, pelayanan kota, industri, dan fasilitas umum lainnya. Jumlah sampel dan metode sampling ditentukan berdasarkan SNI 19-3962-1994. Rata-rata besaran timbulan sampah dalam satuan volume untuk faktor pembagi luas areal dan jumlah jiwa berturutturut adalah 0,4093 L/m²/hari; 2,4646 L/orang/hari; serta sampah khusus pertanian 161,3852 $\mathrm{L} / \mathrm{m}^{2} /$ hari. Komposisi sampah terdiri atas sampah makanan 55,55\%; kertas 14,25\%; plastik 10,14 $\%$; tekstil 4,98 \%; karet 2,82\%; halaman 3,10\%; kayu 2,35\%; kaca 2,01\%; logam ferrous 2,45\%; logam non ferrous 1,61\%; dan sampah lain-lain 0,73\%. Berat jenis sampah sebesar 0,0909 kg/L. Kadar air sampah terbesar adalah industri kecil 52,66 \% dan rasio C/N terbesar adalah sisa makanan 28,84. Komponen sampah berpotensi daur ulang adalah sampah kertas 71,60\%; plastik 94,90 \%; sisa makanan 80,27 \%; kaca 94,77\%; logam ferrous 53,82\%; logam non ferrous 83,07\%; kayu 75,77\%; dan halaman $100 \%$. Rata-rata potensi daur ulang sampah sebesar 72,02\%.
\end{abstract}

Kata kunci: Timbulan sampah, Komposisi sampah, Karakteristik sampah, Potensi daur ulang sampah, Sampah non domestik Kab. Tanah Datar.

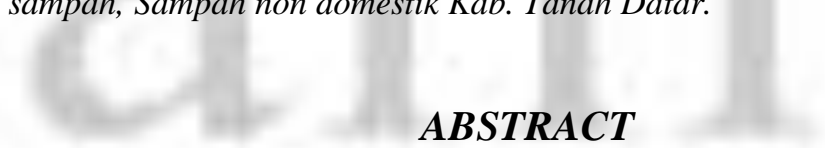

Tanah Datar Regency does not have basic data for solid waste management design, this research is conducted with the purpose of determining waste generation, composition, physical characteristic (specific weight), chemical characteristic (moisture, volatile, fixed carbon, ash, and C/N ratio), and non domestic solid waste potential for recycling from non domestic sources including comercial, institutional, municipal services, industry, and other public facilities. Number of samples and sampling methode are determined based on SNI 19-3962-1994. The solid waste generation are 0,4093 $\mathrm{L} / \mathrm{m}^{2} /$ day; 2,4646 L/people/day; and agriculture solid waste $161,3852 \mathrm{~L} / \mathrm{m}^{2} /$ day. Solid waste composition consist of 55,55\% food wastes; 14,25\% papers; $10,14 \%$ plastics; $4,98 \%$ textiles; 2,82 $\%$ rubber; $3,10 \%$ yard wastes; $2,35 \%$ woods; $2,01 \%$ glasses; $2,45 \%$ ferrous metals; $1,61 \%$ non ferrous metals; and 0,73\% other wastes. Physical characteristic for specific weight is 0,0909 $\mathrm{kg} / \mathrm{L}$. The highest moisture content as chemical characteristic is 52,66\% for small industry and C/N ratio is 28,84 for food wastes. Component of potentially recyclable waste are 71,60\% papers; $94,90 \%$ plastics; 80,27 \% food wastes; 94,77 \% glasses; 53,82 \% ferrous metal; 83,07 \% non ferrous metal, $75,77 \%$ woods; and $100 \%$ yard wastes. The average potential for recycling is $72,02 \%$.

Keyword: Solid waste generation, Solid waste composition, Solid waste characteristic, Solid waste potential for recycling, Tanah Datar Regency non domestic solid waste 


\section{PENDAHULUAN}

Pengertian sampah menurut SNI 19-24542002 adalah limbah yang bersifat padat terdiri dari bahan organik dan bahan anorganik yang dianggap tidak berguna lagi dan harus dikelola agar tidak membahayakan lingkungan dan melindungi investasi pembangunan.

Sampah berdasarkan sumbernya secara garis besar dapat dikelompokkan atas sampah domestik dan sampah non domestik. Sampah non domestik merupakan sampah yang berasal dari sampah komersil, sampah industri, sampah institusi, sampah bangunan, sampah pelayanan kota, lumpur instalasi pengolahan, sisa-sisa lain, dan sampah pertanian (Tchobanoglous, dkk, 1993).

Sampah yang dihasilkan membutuhkan pengelolaan lebih lanjut, jika dibiarkan akan menimbulkan berbagai masalah seperti masalah estetika, vektor penyakit, dan timbulnya pencemaran air tanah. Oleh karena itu, untuk mencegah hal tersebut maka perlu dirancang suatu sistem pengelolaan persampahan sesuai dengan aturan yang ditetapkan dalam UU no. 18 tahun 2008 tentang Pengelolaan Sampah.

Data yang dibutuhkan untuk merancang suatu sistem pengelolaan persampahan adalah data timbulan, komposisi, karakteristik, dan potensi daur ulang sampah.

Kabupaten Tanah Datar adalah wilayah yang belum memiliki data dasar yang dibutuhkan untuk penyusunan master plan pengelolaan persampahan, maka perlu dilakukan penelitian untuk mendapatkan data berupa besaran timbulan, komposisi, karakteristik, dan potensi daur ulang sampah. Penelitian dilakukan pada sumber sampah non domestik, sedangkan pada sumber sampah domestik telah dilakukan pada penelitian sebelumnya oleh Indriyani Zulfa (2013).

Dilakukannya perhitungan pada sumber sampah, selanjutnya dapat dimanfaatkan sebagai informasi dasar dalam perencanaan suatu sistem pengelolaan persampahan Kabupaten Tanah Datar.

Tujuan penelitian ini adalah:
1. Menentukan besaran timbulan dan komposisi sampah non domestik Kab. Tanah Datar;

2. Menentukan karakteristik fisika (berat jenis) dan karakteristik kimia (kadar air, volatile, fixed carbon, abu, dan rasio $\mathrm{C} / \mathrm{N})$ sampah non domestik Kab. Tanah Datar;

3. Menentukan potensi daur ulang sampah non domestik Kab. Tanah Datar.

Definisi timbulan sampah menurut SNI 192454-2002 tentang Tata Cara Teknik Operasional Pengelolaan Sampah Perkotaan adalah banyaknya sampah yang timbul dari masyarakat dalam satuan volume maupun berat per kapita perhari, atau per luas bangunan, atau per panjang jalan.

Komposisi sampah menyatakan komponenkomponen yang terdapat pada sampah, biasanya dinyatakan dengan $\%$ berat. Data komposisi sampah diperlukan dalam penentuan peralatan yang diperlukan, sistem, dan manajemen program dan perencanaan (Tchobanoglous, dkk, 1993).

Salah satu karakteristik fisika sampah adalah berat jenis. Berat jenis merupakan berat material per unit volume (satuan $\mathrm{lb} / \mathrm{ft}^{3}$, lb/yd ${ }^{3}$ ) (Tchobanoglous, dkk, 1993).

Karakteristik kimia sampah salah satunya adalah analisa perkiraan (proximate analysis) terhadap komponen sampah mudah terbakar, yang meliputi (Tchobanoglous, dkk, 1993):

a. Kelembapan (kadar air berkurang pada $105^{\circ} \mathrm{C}$ selama 1 jam);

b. Volatile combustible matter (berat sampah yang berkurang pada pemanasan $\left.950^{\circ} \mathrm{C}\right)$;

c. Fixed carbon (sisa material setelah volatil hilang);

d. Ash (sisa pembakaran).

Karakteristik kimia lainnya yaitu rasio C/N. Rasio karbon dan nitrogen sangat penting dalam memasok unsur hara yang dibutuhkan mikroorganisme selama proses pengomposan berlangsung (Tarigan, 2012).

Potensi daur ulang adalah kemampuan yang ada dalam komponen sampah yang dapat dikembangkan untuk proses pengolahan sampah yang menghasilkan produk baru. 
Macam-macam sampah yang dapat didaur ulang adalah kertas, plastik, kaca, logam non ferrous, logam ferrous, sampah kayu, sampah halaman, sisa makanan, sampah konstruksi dan pemugaran, oli bekas, ban bekas, baterai aki, dan baterai rumah tangga.

Kabupaten Tanah Datar memiliki luas 1336 $\mathrm{km}^{2}$ yang terdiri dari 14 Kecamatan (BPS, 2010). Ibukota kabupaten terdapat di Kota Batusangkar. Sarana non domestik di Kabupaten Tanah Datar sebagai sumber penghasil sampah berasal dari sarana pendidikan, perkantoran, rumah makan, sarana kesehatan, sarana peribadatan, pertokoan, hotel, pasar, penyapuan jalan, industri kecil, pariwisata, sport center, terminal, dan lahan pertanian.

Pengelolaan sampah di Kabupaten Tanah Datar hanya di ibukota kabupaten, sehingga daerah lainnya mengelola sampah di sumber masing-masing dengan cara membakar sampah atau membuang sampah di sembarang tempat.

\section{METODOLOGI}

Tahapan penelitian meliputi studi literatur berupa pengumpulan literatur, jurnal, dan penelitian sebelumnya yang berhubungan. Selanjutnya dilakukan pengumpulan data sekunder seperti gambaran umum lokasi, jumlah sarana non domestik, luas dan jumlah jiwa setiap sarana serta peta pendukung penelitian.

Perencanaan sampling berupa penentuan jumlah sampel, waktu dan tempat penelitian. Jumlah sampel dihitung berdasarkan SNI 19-3964-1994, sehingga diperoleh sampel sebanyak 94 lokasi dari 1085 jumlah total sarana non domestik di Kabupaten Tanah Datar. Jumlah sampel tersebar di 3 kecamatan, untuk memudahkan saat melakukan pengambilan sampel. Kecamatan terpilih yaitu Kec. Lima Kaum mewakili jumlah sarana non domestik paling banyak, Kec. Salimpaung mewakili jumlah sedang, dan Kec. Tanjung Baru mewakili jumlah paling sedikit. Jumlah lokasi sampel di setiap kecamatan berturut-turut adalah 47, 28, dan 19 lokasi.

Menentukan bahwa sampel telah mewakili dari seluruh jumlah sarana, maka dibuktikan dengan evaluasi hasil survei. Keandalan survei sebesar $99,56 \%$ yang berarti jumlah sampel telah mewakili.

Tabel 1 Jumlah Sarana dan Sampel Sampah Non Domestik Kab. Tanah Datar

\begin{tabular}{llrrrrrr}
\hline \multirow{2}{*}{ No } & \multicolumn{2}{c}{ Sarana } & \multicolumn{2}{c}{$\begin{array}{c}\text { Kec.Lima Kaum } \\
\text { (unit) }\end{array}$} & $\begin{array}{c}\text { Kec. Salimpaung } \\
\text { (unit) }\end{array}$ & \multicolumn{2}{c}{$\begin{array}{c}\text { Kec. Tanjung Baru } \\
\text { (unit) }\end{array}$} \\
\cline { 3 - 8 } & & Sarana & Sampel & Sarana & Sampel & Sarana & \multicolumn{1}{c}{ Sampel } \\
\hline 1. & Sarana pendidikan & 47 & 7 & 29 & 5 & 20 & 4 \\
\hline 2. & Sarana Perkantoran & 27 & 5 & 2 & 1 & 1 & 1 \\
\hline 3. & Rumah Makan & 3 & 1 & 2 & 1 & 1 & 1 \\
\hline 4. & Sarana Kesehatan & 4 & 1 & 1 & 1 & 1 & 1 \\
\hline 5. & Sarana Peribadatan & 22 & 2 & 16 & 2 & 20 & 2 \\
\hline 6. & Sarana Pertokoan & 504 & 8 & 52 & 7 & 37 & 6 \\
\hline 7. & Pasar & 1 & 1 & 4 & 2 & 2 & 1 \\
\hline 8. & Industri Kecil & 142 & 14 & 56 & 6 & 5 & 1 \\
\hline 9. & Hotel & 6 & 1 & - & - & - & - \\
\hline 10. & Penyapuan jalan & 17 & 3 & - & - & - & - \\
\hline 11. & Pariwisata & 10 & 1 & 7 & 1 & 6 & 1 \\
\hline 12. & Terminal & 4 & 1 & 2 & 1 & - & - \\
\hline 13. & Sport Center & 1 & 1 & - & - & - & - \\
\hline 14. & Pertanian (jenis panen) & 6 & 1 & 14 & 1 & 13 & 1 \\
\hline Total & & $\mathbf{7 9 4}$ & $\mathbf{4 7}$ & $\mathbf{1 8 5}$ & $\mathbf{2 8}$ & $\mathbf{1 0 6}$ & $\mathbf{1 9}$ \\
\hline & & & & & & & \\
\hline
\end{tabular}


Pengambilan sampel dilakukan selama 8 hari berturut-turut sesuai SNI 19-39641994. Pengambilan sampel dilakukan pada tanggal 10-17 Juni 2013.

Selanjutnya melakukan survei pendahuluan berupa penyebaran kuesioner untuk mendapatkan informasi mengenai sumber sampah dan pengelolaannya. Selain itu, saat penyebaran kuesioner dilakukan pengurusan izin untuk dijadikan sebagai lokasi sampel penelitian.

Pengumpulan data primer berupa besaran timbulan, komposisi, karakteristik fisika dan kimia, serta potensi daur ulang sampah. Pengumpulan data dilakukan di lapangan meliputi pengambilan sampel sampah, perhitungan besaran timbulan, komposisi, karakteristik fisika, dan potensi daur ulang. Selanjutnya sampel sampah dibawa ke laboratorium untuk dihitung karakteristik kimianya.

Pengukuran timbulan berdasarkan SNI 19-3964-1994 meliputi pengukuran timbulan berat dan volume sampah dari masing-masing sampel menurut sumber. Satuan besaran timbulan volume yaitu L/orang/hari, L/tempattidur/hari, dan $\mathrm{L} / \mathrm{m}^{2} /$ hari. Satuan besaran timbulan berat yaitu kg/orang/hari, kg/tempattidur/hari, dan $\mathrm{kg} / \mathrm{m}^{2} /$ hari.

Timbulan sampah yang diukur dikelompokkan berdasarkan luas areal, jumlah jiwa, dan jumlah tempat tidur (SNI 19-3964-1994). Sarana yang diukur berdasarkan jumlah jiwa adalah sarana pendidikan, perkantoran, dan pertokoan. Sarana hotel menggunakan faktor pembagi berdasarkan jumlah tempat tidur. Sedangkan sarana non domestik lainnya menggunakan diukur berdasarkan luas areal.

Faktor koreksi perlu diperhitungkan dalam penentuan besaran timbulan sampah, yang berguna untuk mengoreksi hasil perhitungan yang telah didapat dan untuk mendapatkan besaran timbulan per hari. Faktor koreksi didapat dari: $\mathrm{f}_{\mathrm{k}}=\frac{\overline{\bar{x}}}{\mathrm{x}_{1}}$

$$
\bar{x}=\left(\frac{x_{1}+x_{2}}{2}\right)
$$

dimana:

$\mathrm{x}_{1}=$ data sampling hari pertama

$\mathrm{x}_{2}=$ data sampling hari terakhir

$\bar{x}=$ rata-rata hari sampling pertama dan terakhir

$\mathrm{fk}=$ faktor koreksi

Volume sampah dihitung dengan cara memindahkan sampah dari kantong plastik ke dalam kompaktor dan mengukur tinggi sampah dalam kompaktor sebelum dan setelah dilakukan kompaksi. Kompaksi dilakukan dengan cara menghentakkan kompaktor sebanyak 3 kali ke tanah dengan mengangkat kompaktor setinggi $20 \mathrm{~cm}$. Volume yang digunakan untuk menghitung besaran timbulan adalah volume setelah dilakukan kompaksi. Pengukuran berat sampah dengan menimbang sampah dari masing-masing sampel menggunakan timbangan.

Rumus timbulan per hari:

$=\frac{\text { volume sampah (L) }}{\text { jumlah unit penghasil sampah ( } \mathrm{m}^{2} \text { lorang tempat tidur) }}$

Berat sampah (kg)

$=\overline{\text { jumlah unit penghasil sampah ( } \mathrm{m}^{2} \text { lorang tempat tidur) }}$

Pengukuran komposisi sampah berdasarkan SNI 19-3964-1994, yaitu pemilahan berdasrkan sampah organik (sampah makanan, kertas, plastik, tekstil, karet, sampah halaman, kayu) dan sampah anorganik (kaca, logam ferrous, logam non ferrous, dan lain-lain) dari masing-masing sampel.

Penentuan berat sampah masing-masing komponen dengan cara komponen yang telah dipilah ditimbang beratnya. Sehingga persen komposisi didapat dari persen berat masing-masing komponen dibagi dengan berat total sampah keseluruhan.

Rumus komposisi (\% berat):

$=\frac{\text { berat komponen sampah (kg) }}{\text { berat total sampah yang diukur (kg) }}$

Perhitungan karakteristik sampah berupa berat jenis didapat dari pengukuran timbulan yaitu menggunakan data 
volume setelah kompaksi dan berat sampah.

Menurut Tchobanoglous (1993), rumus menentukan berat jenis $(\mathrm{kg} / \mathrm{L})$ :

$=\frac{\text { berat } \operatorname{sampah}(\mathrm{kg})}{\text { volume sampah }(\mathrm{L})}$

Penentuan potensi daur ulang sampah dengan melakukan pemilahan sampahsampah yang dapat didaur ulang dari sampah yang telah dipisahkan menurut komposisinya dan ditimbang beratnya.

Menurut Anwar (2011), rumus potensi daur ulang sampah per sumber $(\%)$ :

$$
=\frac{\text { berat komponen dapat didaur ulang }}{\text { berat total sampah dari sumber }} \times 100 \%
$$

Rumus potensi daur ulang sampah perkomponen (Anwar, 2011):

$=\frac{\text { berat komponen dapat didaur ulang }}{\text { berat total komponen sampah }} \times 100 \%$

Setelah penelitian di lapangan selesai selama 8 hari, maka sampel sampah dibawa ke laboratorium untuk menghitung karakteristik kimia. Pengambilan sampel dilakukan pada musim peralihan, sehingga sampel sampah, namun pada hari terakhir pengambilan sampel tidak terjadi hujan. Data primer yang dihitung yaitu proximate analysis (kadar air, volatile, fixed carbon, dan abu) dan rasio $\mathrm{C} / \mathrm{N}$.

Pengukuran proximate analysis menggunakan metode pemanasan menggunakan oven dan furnace berdasarkan Modul Laboratorium Lingkungan Jurusan Teknik Lingkungan Unand. Berat sampel sebelum dan setelah pemanasan dijadikan bahan analisa perhitungan. Sampel sampah yang diukur adalah sampah sisa makanan, kertas, halaman, pertanian, dan industri kecil yang terdiri dari industri makanan.

Pemanasan pada temperatur $105{ }^{\circ} \mathrm{C}$ pada oven untuk menentukan kadar air. Rumus kadar air (\%):

$=\frac{\text { berat cawan isi - berat cawan } 105{ }^{\circ} \mathrm{C}}{\text { berat cawan isi - berat cawan kosong }}$ x $100 \%$

Sampel sampah hasil penentuan kadar air dipanaskan di oven pada temperatur 600 ${ }^{\circ} \mathrm{C}$ untuk menentukan kadar volatile. Rumus volatile (\%): $=\frac{\text { berat cawan } 150^{\circ} \mathrm{C}-\text { berat cawan } 600{ }^{\circ} \mathrm{C}}{\text { berat cawan isi }- \text { berat cawan kosong }} \times 100 \%$

Pemanasan terakhir menentukan kadar abu atau sisa pembakaran pada furnace dengan temperatur $900{ }^{\circ} \mathrm{C}$. Rumus kadar abu $(\%)$ :

$=\frac{\text { berat cawan } 9000^{\circ} \mathrm{C}-\text { berat cawan kosong }}{\text { berat cawan isi - berat cawan kosong }} \times 100 \%$ Selisih dari perhitungan sebelumnya sebagai penentuan kadar fixed carbon.

Rumus fixed carbon (\%):

$=100 \%-(\% \mathrm{k}$. air $+\% \mathrm{k}$. volatile $+\% \mathrm{k}$. $\mathrm{Abu})$

Pengukuran rasio $\mathrm{C} / \mathrm{N}$ untuk komponen sampah sisa makanan, halaman, industri kecil, dan pertanian. Penentuan rasio $\mathrm{C} / \mathrm{N}$ didapat dari perbandingan nilai $\mathrm{C}$ Organik dengan kadar N-Total. Perhitungan kadar C-Organik dengan metode spektrofotometri dan kadar $\mathrm{N}$ Total dengan metode Kjelhdal yaitu dengan sistem destilasi.

Rumus kadar C-Organik (\%):

$=$ konsentrasi sampel $\mathrm{x} 0,01 \mathrm{x}$ faktor koreksi

Rumus kadar N-total (\%):

$=\{$ titar contoh $(\mathrm{ml})-$ titar blanko $(\mathrm{ml})\} \mathrm{x}$

Normalitas larutan baku $\mathrm{H}_{2} \mathrm{SO}_{4}$ x 14 x

$100 \times \mathrm{mg}$ contoh $^{-1} \mathrm{x}$ faktor koreksi

Faktor koreksi

$=100 /(100-\%$ kadar air $)$

\section{HASIL DAN PEMBAHASAN}

\section{Timbulan Sampah}

Rata-rata besaran timbulan sampah berdasarkan sarana ditampilkan pada Tabel 2 berikut. Timbulan sampah pertanian hanya dihasilkan pada waktu panen, dalam hal ini diperkirakan area pertanian akan menghasilkan sampah selama masa panen 8 hari setiap 3 bulan sebagai masa bercocok tanam.

Besaran timbulan sampah per hari dihitung berdasarkan jumlah orang, meliputi sarana pendidikan, perkantoran, dan pertokoan. Timbulan sampah per hari yang dihasilkan setiap luas areal diperuntukkan pada sarana rumah makan, 
sarana kesehatan, sarana peribadatan, pasar, penyapuan jalan, industri kecil, pariwisata, sport center, terminal, dan pertanian. sedangkan sumber sampah di hotel dihitung besaran timbulan per hari berdasarkan jumlah tempat tidur.

Tabel 2 berikut menampilkan rata-rata timbulan sampah per hari yang dihasilkan setiap sarana non domestik di Kabupaten Tanah Datar.

Tabel 2 Rata-rata Timbulan Sampah Berdasarkan Sarana

\begin{tabular}{lcc}
\hline \multicolumn{1}{c}{ Sarana } & (L/hari) & Kg/hari \\
\hline Per orang & & \\
\hline Pendidikan & 0.2489 & 0.0093 \\
\hline Perkantoran & 1.5112 & 0.0635 \\
\hline Pertokoan & 5.6338 & 0.2759 \\
\hline Per meter & & \\
\hline Rumah makan & 0.3260 & 0.0569 \\
\hline Sarana kesehatan & 0.0554 & 0.0010 \\
\hline Sarana Peribadatan & 0.0155 & 0.0007 \\
\hline Pasar & 0.2728 & 0.1636 \\
\hline Penyapuan Jalan & 1.2969 & 0.0725 \\
\hline Industri Kecil & 1.7245 & 0.4124 \\
\hline Pariwisata & 0.2736 & 0.0050 \\
\hline Sport center & 0.0751 & 0.0014 \\
\hline Terminal & 0.0482 & 0.0083 \\
\hline Pertanian & 161.3852 & 0.8173 \\
\hline Per Tempat tidur & & \\
\hline Hotel & 1.3732 & 0.2131 \\
\hline
\end{tabular}

\section{Metode Penggunaan Satuan}

Data besaran timbulan nantinya akan digunakan sebagai informasi dasar dalam perancangan pengelolaan persampahan. Sehingga rata-rata timbulan dijadikan acuan untuk memperhitungkan besaran timbulan yang dihasilkan oleh sarana non domestik pada suatu kawasan dengan cara memproyeksikan rata-rata timbulan sampah sesuai dengan jumlah unit masing-masing sarana non domestik.

Rata-rata besaran timbulan ditampilkan dalam satuan jumlah orang dan luas areal. Sedangkan untuk hotel yang menggunakan satuan berdasarkan jumlah tempat tidur, dikonversikan ke dalam satuan luas areal.

Besaran timbulan berdasarkan luas areal sarana non domestik sebesar 0,4093 $\mathrm{L} / \mathrm{m}^{2} /$ hari atau $0,0723 \mathrm{~kg} / \mathrm{m}^{2} /$ hari. Besaran timbulan berdasarkan jumlah orang sarana non domestik sebesar 2,4646 L/orang/hari atau 0,1162 kg/orang/hari. Besaran timbulan khusus untuk lahan pertanian sebesar 161,3852 $\mathrm{L} / \mathrm{m}^{2} /$ hari atau $0,8173 \mathrm{~kg} / \mathrm{m}^{2} /$ hari.

Tabel 3 berikut menampilkan penggunaan satuan timbulan per sumber untuk perencanaan

Tabel 3 Penggunaan Satuan Timbulan Per Sumber Untuk Perencanaan

\begin{tabular}{clrl}
\hline No & \multicolumn{1}{c}{ Sarana } & Besaran Timbulan & \multicolumn{1}{c}{ Keterangan } \\
\hline 1 & Rumah Makan, Sarana & $0.4093 \mathrm{~L} / \mathrm{m}^{2} / \mathrm{hari}$ & Faktor pembagi luas areal \\
& Kesehatan, Sarana & $0.0723 \mathrm{~kg} / \mathrm{m}^{2} / \mathrm{hari}$ & \\
& Peribadatan, Hotel, & & \\
& PasarPenyapuan Jalan, & & \\
& Industri Kecil, Pariwisata, & & \\
& Sport Center, Terminal & $2.4646 \mathrm{~L} / \mathrm{orang} / \mathrm{hari}$ & Faktor pembagi jumlah jiwa \\
\hline 2 & Pendidikan, Perkantoran & $0.1162 \mathrm{~kg} / \mathrm{orang} / \mathrm{hari}$ & \\
\hline Pertokoan & Pertanian & $161.3852 \mathrm{~L} / \mathrm{m}^{2} / \mathrm{hari}$ & Faktor pembagi luas areal \\
& & $0.8173 \mathrm{~kg} / \mathrm{m}^{2} / \mathrm{hari}$ & Besaran timbulan sampah khusus \\
& & pertanian dihasilkan pada waktu \\
& & & panen \\
\hline
\end{tabular}

\section{Komposisi Sampah}

Komponen sampah yang mempunyai komposisi terbesar yaitu sampah makanan sebesar 55,55 \%. Komposisi sampah lainnya yaitu sampah kertas
$14,25 \%$; plastik 10,14\%; tekstil 4,98 \%; sampah halaman $3,10 \%$; karet 2,82 \%; logam ferrous $2,45 \%$; kayu 2,35 \%; kaca $2,01 \%$; logam non ferrous $1,61 \%$ dan sampah lain-lain $0,73 \%$. 
Komposisi sampah digolongkan menjadi komposisi sampah basah dan kering. Komposisi sampah basah sebesar 61,00 $\%$ yang terdiri dari sampah makanan, halaman, dan kayu. Sedangkan sampah kering sebesar $39 \%$ yangh terdiri dari sampah kertas, plastik, tekstil, karet, kaca, logam ferrous, logam non ferrous, an sampah lain-lain.

Selain itu komposisi sampah juga digolongkan menjadi sampah organik dan anorganik. Komposis sampah organik sebesar 93,19\% yang terdirid dari sampah makanan, kertas, plastik, tekstil, karet, halaman, dan kayu. Sedangkan komposisi sampah anorganik sebesar 6,81\% terdiri dari sampah kaca, logam ferrous, logam non ferrous, dan sampah lain-lain.

Perhitungan komposisi sampah tidak termasuk komposisi sampah pertanian. sampah pertanian terdiri dari komponen sampah halaman $100 \%$.

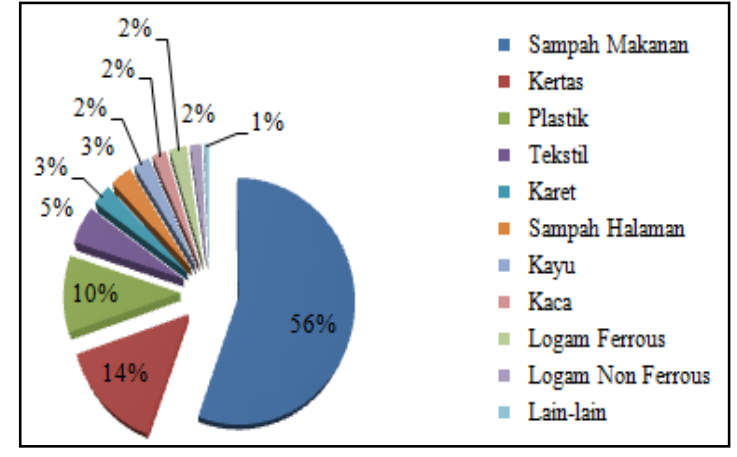

Gambar 1 Komposisi Sampah

\section{Karakteristik Sampah}

Karakteristik fisika sampah yang dihitung adalah berat jenis sampah. Berat jenis Datar berkisar antara 0,0116$0,2494 \mathrm{~kg} / \mathrm{L}$; dengan rata-rata sebesar $0,0909 \mathrm{~kg} / \mathrm{L}$. Berat jenis terbesar terdapat pada sampah pasar yaitu $0,2494 \mathrm{~kg} / \mathrm{L}$ dan yang terkecil $0,0116 \mathrm{~kg} / \mathrm{L}$ yaitu sampah pertanian.

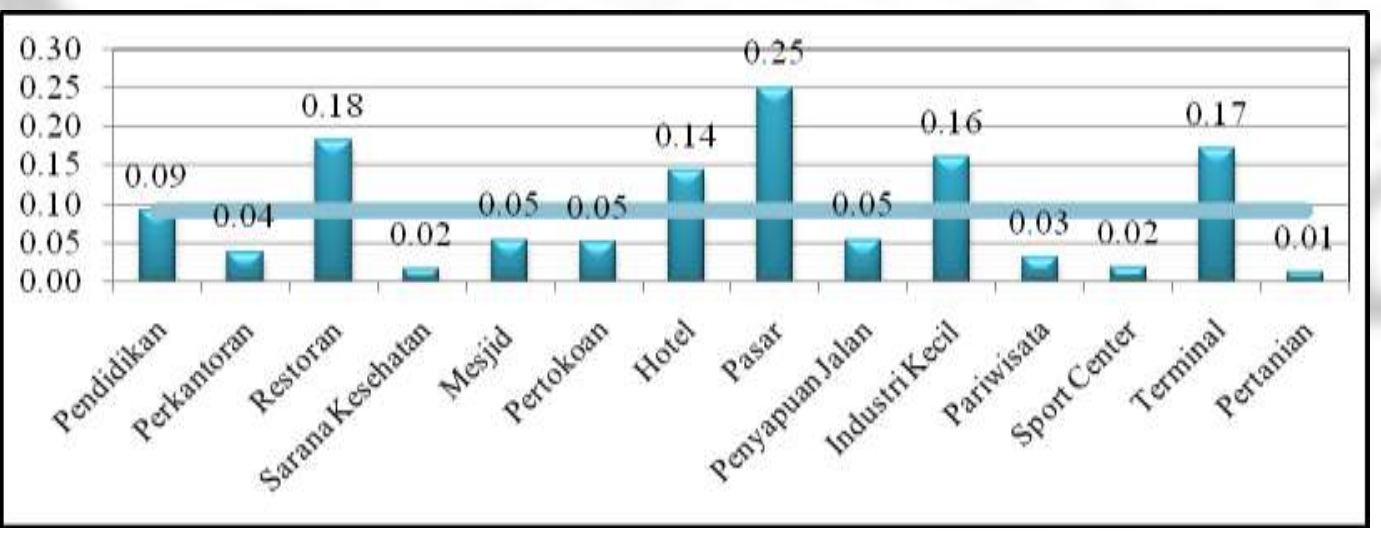

Gambar 2 Berat Jenis Sampah

\section{Karakteristik kimia}

Perhitungan karakteristik kimia berupa proximate analysis meliputi kadar air, volatile, fixed carbon, dan abu.

Kadar air terbesar terdapat pada sampah makanan yaitu sebesar 52,28\% dan industri makanan 52,66\%. Kadar volatile terbesar pada sampah halaman 75,64\%; kertas 82,62 \%; dan pertanian 75,19\%.

Kandungan kadar air sampah dapat menentukan pengolahan sampah dengan cara pengomposan. Rentang kadar air optimum untuk proses pengomposan secara aerobik adalah 50-60\% (Tchobanoglous, dkk, 1993). Maka sampah makanan dan sampah industri makanan dapat dijadikan bahan mentah kompos.

Kadar volatile dapat memperkirakan seberapa besar efektifitas pengurangan (reduksi) sampah dengan menggunakan metode pembakaran berteknologi tinggi (insinerator). Range kadar volatile sampah yang optimal untuk diolah dengan metode pembakaran adalah 60$65 \%$, sehingga untuk sampah pertanian, 
halaman, dan kertas memungkinkan pengolahan menggunakan insinerator.

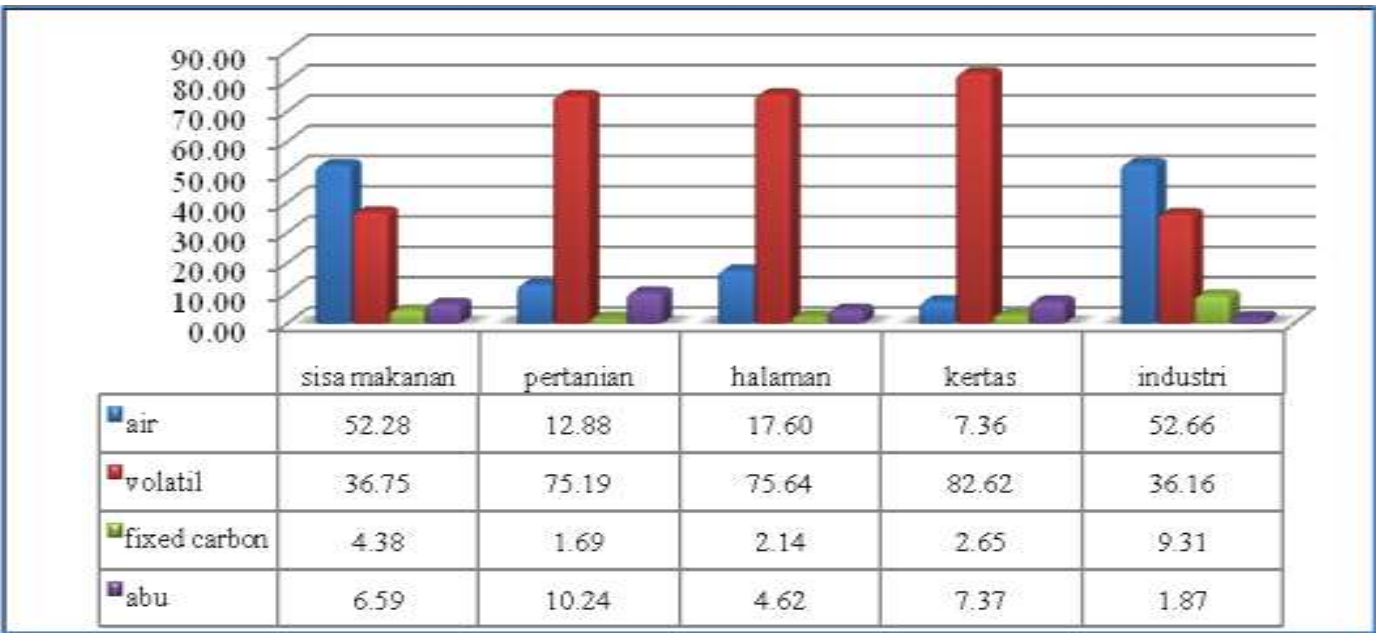

Gambar 3 Proximate Analysis Sampah

Karakteristik kimia sampah berupa rasio $\mathrm{C} / \mathrm{N}$ terbesar terdapat pada sampah industri makanan 25,49. Selanjtnya sampah makanan 24,84; halaman 11,69; dan pertanian 9,36.

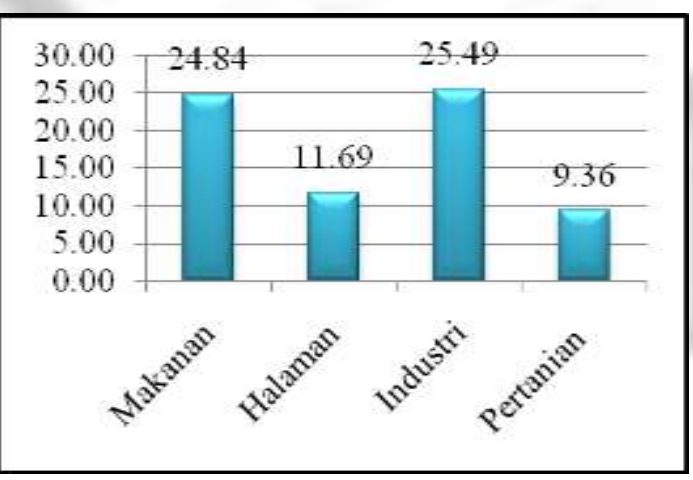

\section{Gambar 4 Rasio C/N Sampah}

Sampah yang memiliki rasio $\mathrm{C} / \mathrm{N}$ sebesar 20-25, dapat digunakan sebagai bahan mentah kompos (Tchobanoglous, 1993). Sehingga sampah makanan dan industri makanan baik dijadikan bahan mentah kompos.

Potensi Daur Ulang Berdasarkan Komponen Sampah

Komponen sampah yang berpotensi daur ulang adalah sampah kertas, plastik, sisa makanan, kaca, logam, kayu, dan sampah halaman. Sedangkan sampah karet, tekstil, dan sampah lain-lain termasuk sampah yang tidak berpotensi daur ulang. Sampah yang memiliki potensi daur ulang terbesar adalah sampah halaman
$100 \%$; sampah plastik 94,90\%; dan sampah kaca 94,77\%.

Rata-rata potensi daur ulang sampah non domestik Kab. Tanah Datar sebesar 72,02 $\%$. Pengelompokan sampah berdasarkan sampah basah dan kering, menghasilkan sampah basah berpotensi daur ulang sebesar 46,97 \%; yaitu sampah makanan $39,00 \%$; sampah halaman $6,24 \%$ dan kayu $1,73 \%$. Potensi daur ulang sampah kering sebesar $25,05 \%$ meliputi $11,69 \%$ kertas; $8,80 \%$ plastik; $1,83 \%$ kaca; $1,52 \%$ logam ferrous; dan 1,21 \% logam non ferrous.

Pengelompokan berdasarkan sampah organik dan anorganik, sampah organik berpotensi daur ulang 67,46 \% dan sampah anorganik berpotensi daur ulang $4,56 \%$. Sampah organik bisa daur ulang terdiri dari sampah makanan, kertas, plastik, sampah halaman, dan kayu serta sampah anorganik terdiri dari kaca, logam ferrous, dan logam non ferrous. 


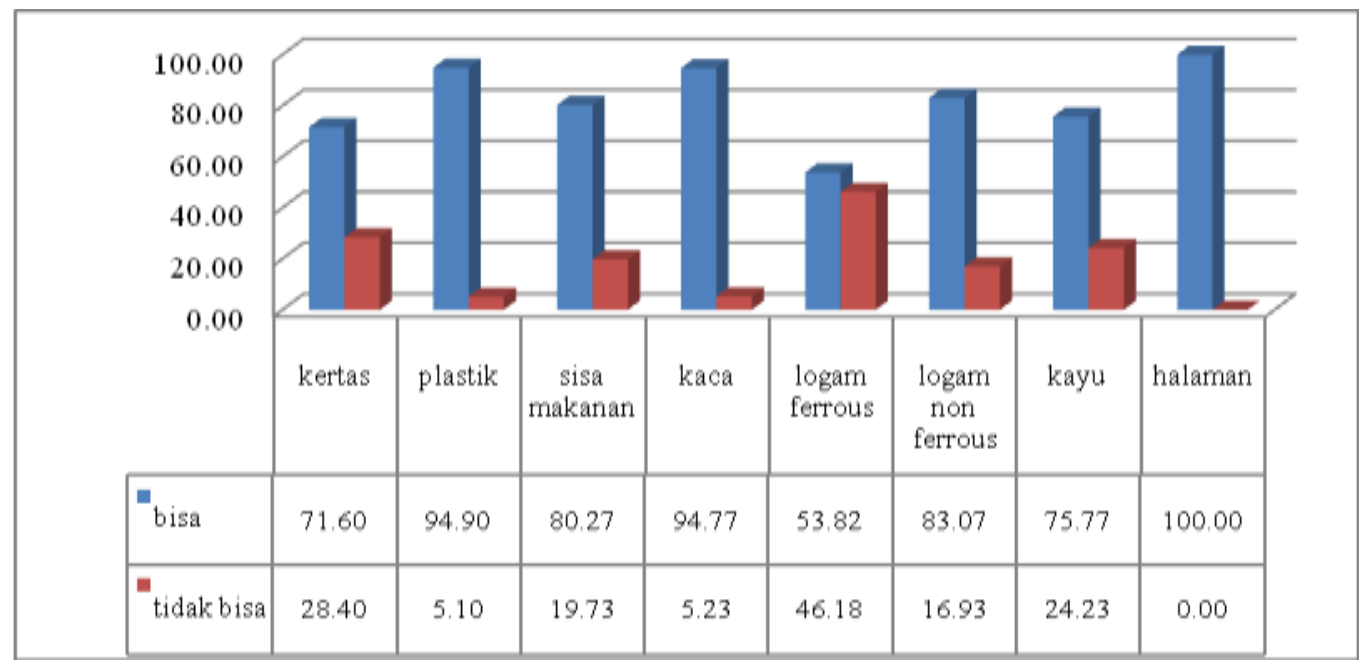

Gambar 5 Potensi Daur Ulang Sampah Berdasarkan Komponen Sampah

\section{Potensi Daur Ulang Berdasarkan Sumber Sampah}

Total berat sampah yang dihasilkan di Kabupaten Tanah Datar sebanyak 72,02 $\%$ berpotensi daur ulang. Sumber sampah penghasil terbesar sampah berpotensi daur ulang adalah sampah pasar. Pasar merupakan sumber sampah yang menghasilkan sampah terbanyak per hari.
Sampah yang dihasilkan berupa sisa makanan sebagai hasil kegiatan komersil merupakan sampah basah yang dapat dijadikan bahan mentah kompos, sedangkan sampah kering seperti kertas dan plastik dapat didaur ulang. Sampah pertanian yang menghasilkan sampah halaman, dapat juga dijadikan sebagai bahan mentah kompos.

Tabel 4 Rekapitulasi Daur Ulang Sampah

\begin{tabular}{|c|c|c|c|c|c|}
\hline \multirow{3}{*}{ No } & \multirow{3}{*}{ Sarana } & \multicolumn{4}{|c|}{ Daur Ulang Sampah (\%) } \\
\hline & & \multicolumn{2}{|c|}{ Bisa Daur Ulang } & \multirow{2}{*}{ Tidak Bisa Daur Ulang } & \multirow{2}{*}{ Total } \\
\hline & & Kompos & Daur Ulang & & \\
\hline 1. & Pendidikan & 0.06 & 0.12 & 0.02 & 0.20 \\
\hline 2. & Perkantoran & 0.00 & 0.01 & 0.00 & 0.02 \\
\hline 3. & Rumah makan & 0.07 & 0.02 & -2 & 0.13 \\
\hline 4. & Sarana kesehatan & 0.00 & 0.01 & 0.01 & 0.02 \\
\hline 5. & Mesjid & 0.00 & 0.00 & 0.00 & 0.01 \\
\hline 6. & Pertokoan & 0.00 & 0.01 & 0.00 & 0.01 \\
\hline 7. & Hotel & 0.02 & 0.01 & 0.01 & 0.03 \\
\hline 8. & Pasar & 42.12 & 23.86 & 27.50 & 93.48 \\
\hline 9. & Penyapuan Jalan & 0.04 & 0.01 & 0.01 & 0.06 \\
\hline 10. & Industri Kecil & 0.16 & 0.00 & 0.06 & 0.23 \\
\hline 11. & Pariwisata & 0.11 & 0.06 & 0.01 & 0.18 \\
\hline 12. & Sport center & 0.26 & 0.35 & 0.06 & 0.67 \\
\hline 13. & Terminal & 0.73 & 0.58 & 0.25 & 1.56 \\
\hline 14. & Pertanian & 3.40 & 0.00 & 0.00 & 3.40 \\
\hline & Rata-rata & 46.97 & 25.05 & 27.98 & 100.00 \\
\hline
\end{tabular}


Proyeksi besaran timbulan sampah yang dihasilkan seluruh sarana non domestik Kab. Tanah Datar adalah $51.510 \mathrm{~kg} / \mathrm{hari}$, tidak termasuk sampah pertanian, karena sampah pertanian dihasilkan pada waktu tertentu saja. Total sampah diperoleh dengan menganggap setiap sarana non domestik menghasilkan sampah pada hari yang sama.

Perhitungan potensi daur ulang sampah sebesar 46,97 \% sampah basah yang selanjutnya dapat diolah dengan cara pengomposan dan $25,05 \%$ sampah kering yang selanjutnya dapat didaur ulang. Sehingga diperoleh jumlah sampah yang dapat dikompos sebanyak $24.194 \mathrm{~kg} / \mathrm{hari}$ dan jumlah sampah daur ulang 12.903 $\mathrm{kg} / \mathrm{hari}$.

Jumlah sampah pertanian yang dihasilkan setiap kali panen sekitar 113.000 ton, dengan asumsi seluruh areal pertanian melakukan panen selama 8 hari yang diperkirakan sebagai masa panen.

\section{Kajian Awal Penerapan Daur Ulang}

Hasil penelitian potensi daur ulang sampah Kab. Tanah Datar didapatkan potensi daur ulang sampah basah lebih besar dari pada sampah kering. Melihat besarnya potensi daur ulang, nilai ekonomis, teknologi, dan komposisi sampah dapat disimpulkan bahwa penerapan daur ulang di Kab. Tanah Datar baru bisa diprioritaskan untuk sampah basah berupa sampah makanan dan sampah halaman serta sampah kering berupa plastik, kertas, kaca, kaleng, dan logam. Pengolahan sampah untuk sampah basah adalah pengomposan sedangkan sampah kering berupa daur ulang.

Kegiatan daur ulang dapat diawali dengan upaya pemisahan sampah dari sumber penghasil sampah berdasarkan komponen sampah. Proses pengangkutan sebaiknya juga dibedakan siklusnya, dimana untuk sampah basah diangkut setiap harinya untuk menghindari bau dan pertumbuhan lalat dan sampah kering dapat diangkut untuk sampah beberapa hari karena tidak akan menimbulkan bau.

Pengelolaan sampah basah dimulai dengan penerapan pengomposan skala invidual. Penerapan ini melibatkan masyarakat secara langsung untuk melakukan pemilahan sampah serta pengolahan sampah. Kegiatan seperti pengomposan sampah basah skala individual/komposter rumah tangga merupakan salah satu contoh kongkrit dalam penerapan pengomposan skala individual, sedangkan untuk skala kabupaten, Dinas Kebersihan dan Pertamanan (DKP) dapat menyediakan lahan di TPA untuk kegiatan pengomposan sampah basah.

Komponen sampah yang akan dijadikan bahan mentah kompos perlu dilakukan penelitian lebih lanjut mengenai karakteristik kimia sampah. Hal ini dilakukan untuk mendapatkan data yang dibutuhkan dalam merancang pengolahan sampah dengan cara pengomposan. Adapun karakteristik kimia tersebut adalah biodegrabilitas dari komponen sampah organik, produksi bau, dan pertumbuhan lalat.

Penentuan karakteristik fisika berupa perhitungan ukuran partikel dan distribusi ukuran juga perlu dilakukan untuk menentukan jenis fasiltas pengolahan, terutama untuk memisahkan partikel besar dan kecil.

Sampah yang tidak bisa didaur ulang dengan cara pengomposan atau proses daur ulang maka akan diolah di TPA dengan cara penimbunan (landfilling).

\section{SIMPULAN}

1. Rata-rata besaran timbulan volume dan berat sampah non domestik Kab. Tanah Datar Tahun 2013 persatuan luas adalah $0,4093 \mathrm{~L} / \mathrm{m} 2 /$ hari dan 0,0723 $\mathrm{kg} / \mathrm{m} 2 /$ hari, persatuan jiwa adalah 2,4646 L/orang/hari dan 0,1162 kg/orang/hari, dan sampah khusus pertanian 161,3852 L/m2/hari dan 0,8173 kg/m2/hari.

2. Berdasarkan sumbernya, satuan timbulan sampah non domestik Kab. Tanah Datar berbeda-beda. Timbulan sampah fasilitas pendidikan 0,2489 L/orang/hari, fasilitas perkantoran $1,5112 \mathrm{~L} /$ orang/hari, rumah makan $0,3260 \mathrm{~L} / \mathrm{m} 2 /$ hari, sarana kesehatan $0,0554 \mathrm{~L} / \mathrm{m} 2 / \mathrm{hari}$, mesjid 0,0155 $\mathrm{L} / \mathrm{m} 2 /$ hari, pertokoan 5,6338 L/orang/hari, hotel $\quad 1,3732$ L/tempattidur/hari, pasar 0,2756 $\mathrm{L} / \mathrm{m} 2 /$ hari, penyapuan jalan 1,2969 
$\mathrm{L} / \mathrm{m} 2 /$ hari, industri kecil 1,7245 $\mathrm{L} / \mathrm{m} 2 /$ hari, pariwisata $0,2736 \mathrm{~L} / \mathrm{m} 2 /$ hari, Sport Center $0,0751 \mathrm{~L} / \mathrm{m} 2 / \mathrm{hari}$, terminal $0,0482 \mathrm{~L} / \mathrm{m} 2 / \mathrm{hari}$, dan pertanian $161,3852 \mathrm{~L} / \mathrm{m} 2 /$ hari.

3. Rata-rata komposisi sampah non domestik Kab. Tanah Datar didominasi oleh sampah organik sebesar 93,19\% yang terdiri atas sampah sisa makanan $55,55 \%$; kertas 14,25\%; plastik $10,14 \%$; tekstil $4,98 \%$; karet $2,82 \%$; sampah halaman 3,10\%; dan kayu $2,35 \%$. Sedangkan sampah anorganik sebanyak $6,81 \%$ yang terdiri atas kaca $2,01 \%$; logam ferrous $2,45 \%$; logam non ferrous $1,61 \%$; dan sampah lainlain $0,73 \%$. Sedangkan komposisi sampah pertanian seluruhnya terdiri dari sampah halaman.

4. Rata-rata berat jenis sampah non domestik Kab. Tanah Datar adalah $0,0909 \mathrm{~kg} / \mathrm{L}$.

5. Proximate analysis sampah sisa makanan, halaman, kertas, industri kecil, dan pertanian berturut-turut untuk kadar air adalah 52,28; 17,60; 7,36; 52,$66 ; 12,88$; kadar volatile 36,75 ; 75,$64 ; 82,62 ; 36,16 ; 75,19$; kadar fixed carbon 4,$38 ; 2,14 ; 2,65 ; 9,31 ; 1,69$; dan kadar abu 6,59; 4,62; 7,37; 1,87; 10,24.

6. Rasio C/N sampah non domestik Kab. Tanah Datar adalah sisa makanan 28,84; halaman 11,69; industri makanan 25,49; dan pertanian 9,36.

7. Rata-rata potensi daur ulang sampah non domestik Kab. Tanah Datar berdasarkan komponen sampah adalah sampah kertas $71,60 \%$; sampah plastik 94,90\%; sampah makanan 80,27\%; sampah kaca 94,77\%; sampah logam ferrous 53,82\%; sampah logam non ferrous $83,07 \%$; sampah kayu $75,77 \%$; dan sampah halaman $100 \%$.
8. Rata-rata potensi daur ulang sampah non domestik Kab. Tanah Datar berdasarkan sumber sampah adalah sarana pendidikan $89,21 \%$; sarana perkantoran 78,62\%; rumah makan $66,44 \%$; sarana kesehatan 51,30\%; mesjid 82,05\%; sarana pertokoan $86,27 \%$; hotel $84,98 \%$; pasar $70,58 \%$; penyapuan jalan 91,26\%; industri kecil $71,76 \%$; pariwisata $92,48 \%$; sport center $91,41 \%$; terminal $83,80 \%$; dan pertanian $100 \%$.

9. Potensi daur ulang sampah non domestik Kab. Tanah Datar adalah $72,02 \%$; yang terdiri dari potensi daur ulang sampah basah 46,97\% dan potensi daur ulang sampah kering $25.05 \%$ atau sampah organik $67.46 \%$ dan sampah anorganik $4,56 \%$.

\section{DAFTAR PUSTAKA}

Badan Pusat Statistik. 2010. Tanah Datar Dalam Angka 2010. BPS Kabupaten Tanah Datar

SNI 19-3964-1994. Tentang Metode Pengambilan dan Pengukuran Contoh Timbulan dan Komposisi Sampah Perkotaan

Tarigan. 2012. Pembuatan Pupuk Organik Cair dengan Memanfaatkan Limbah Padat Sayuran Kubis (Brassica Aleracege. L) dan Isi Rumen Sapi. (http://repository.usu.ac.id/handle/1234 56789/27866, diakses tanggal 30 Agustus 2013)

Tchobanoglous, G, Theisen, H, Vigil, S. 1993. Integrated Solid Waste Management : Engineering Principles and Management Issues. Mc. GrawHill, Inc: New York 